\title{
A new Centromerus Dahl, 1886 from the Kirov Area, Russia (Aranei: Linyphiidae)
}

\section{Новый вид рода Centromerus Dahl, 1886 из Кировской области (Россия) (Aranei: Linyphiidae)}

\author{
Andrei V. Tanasevitch*, Sergei L. Esyunin**

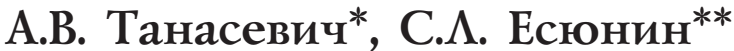

\footnotetext{
* Institute of Ecology and Evolution, Russian Academy of Sciences, Leninsky prospekt, 33, Moscow 119071, Russia. E-mail: tanasevitch@gmail.com

* Институт проблем экологии и эволюции РАН, Ленинский проспект, 33, Москва 119071, Россия.

** Perm State University, Bukireva Str., 15, Perm 614990, Russia. E-mail: Sergei.Esyunin@psu.ru

** Пермский государственный университет, ул. Букирева, 15, Пермь, 614990, Россия.
}

KEY WORDS: Spider, Centromerus, new species, Russian Plain, taiga.

КЛЮЧЕВЫЕ СЛОВА: Паук, Centromerus, новый вид, Русская равнина, тайга.

ABSTRACT. A new species, Centromerus nurgush sp.n., is described from the Kirov Area, European part of Russia. The species is similar to the Siberian $C$. clarus (L. Koch, 1879), but differs well in structure of the genitalia of both sexes.

РЕЗЮМЕ. Новый вид, Centromerus nurgush sp.n., описан из Кировской области. Вид близок к сибирскому C. clarus (L. Koch, 1879), но хорошо отличается от него деталями строения гениталий обоих полов.

The European part of Russia is generally considered to be well-studied with respect to its spider fauna. Indeed, new species are still being described only from the southern regions supporting steppe or semi-desert habitats [see Tanasevitch, 1987, 1993, 2004; Tanasevitch, Piterkina, 2007; Gnelitsa, 2008; Gnelitsa, Ponomarev, 2010, etc.]. The more so unusual is the discovery of a new linyphiid species in the Kirov Area, within the subzone southern taiga (= boreal coniferous) forest. The araneofauna of that area is generally well-known, amounting to 296 species from 27 families [Esyunin et al., 2011]. The new Centromerus is another species to be added to that list. As it seems highly unlikely that it is a regional endemic, further collecting efforts are thus necessary.

The new species was found in the Nurgush Nature Reserve situated in the centre of the Kirov Area, at a bend of Vyatka River. The Reserve's relief is floodplain, every spring being almost fully inundated for 2 5 days. The meadow where the specimens were taken is located amid a mixed forest.

\section{Material and methods}

The paper is based on the spider material collected using pitfall traps by Lyudmila Tselishcheva in the
Nurgush Nature Reserve, Kirov Area. The type specimens are shared between the collections of ZMMU, PSU and MHNG.

In the description, the sequence of leg segment measurements is as follows: femur + patella + tibia + metatarsus + tarsus. All measurements are given in $\mathrm{mm}$. Scale lines in the figures correspond to $0.1 \mathrm{~mm}$.

The terminology of genitalic structures in Micronetinae follows that of Tanasevitch [1995] and Saaristo, Tanasevitch [1996].

The following abbreviations are used in the text and figures: $\mathrm{Ca}$ - carina; DPS — distal part of scape; $\mathrm{E}$ - embolus; $\mathrm{Fe}$ - femur; L - lamella characteristica; MHNG - Muséum d'histoire naturelle, Geneva, Switzerland; Ms — membrosclerum; Mt - metatarsus; PS - proscape; PSU — Perm State University, Perm, Russia; R — radix; RA — radical apophysis; $\mathrm{Ti}$ - tibia; TmI - position of trichobothrium on metatarsus I; X - spine-like process; $Z$ - see palp description; ZMMU - Zoological Museum of the Moscow State University, Moscow, Russia.

\section{Description}

Centromerus nurgush sp.n. Figs 1-10.

HOLOTYPE: O' (ZMMU), RUSSIA, Kirov Area, Kotel'nich District, Nurgush Nature Reserve, between Vishkil' and Borovka, bank of Prost' River, 57.997222 ${ }^{\circ} \mathrm{N} 48.421667^{\circ} \mathrm{E}$, flood-plain herbaceous meadow with Bromopsis inermis, Carex acuta, Filipendula ulmaria, pitfall traps, 17-24.VI.2011, leg. L. Tselishcheva.

PARATYPES: $4 \sigma^{\gamma} \sigma^{\gamma}, 2$ 우 (ZMMU), $3 \sigma^{\top} \sigma^{\gamma}, 2$ 우 (PSU), 2 $\sigma^{\top} \sigma^{\top}, 2$ 90 (MHNG), same locality, pitfall traps, 20.V.-11.VII.2011, leg. L. Tselishcheva.

NAME. The species name is a noun in opposition referring to the Nurgush Nature Reserve, the locus typicus. 

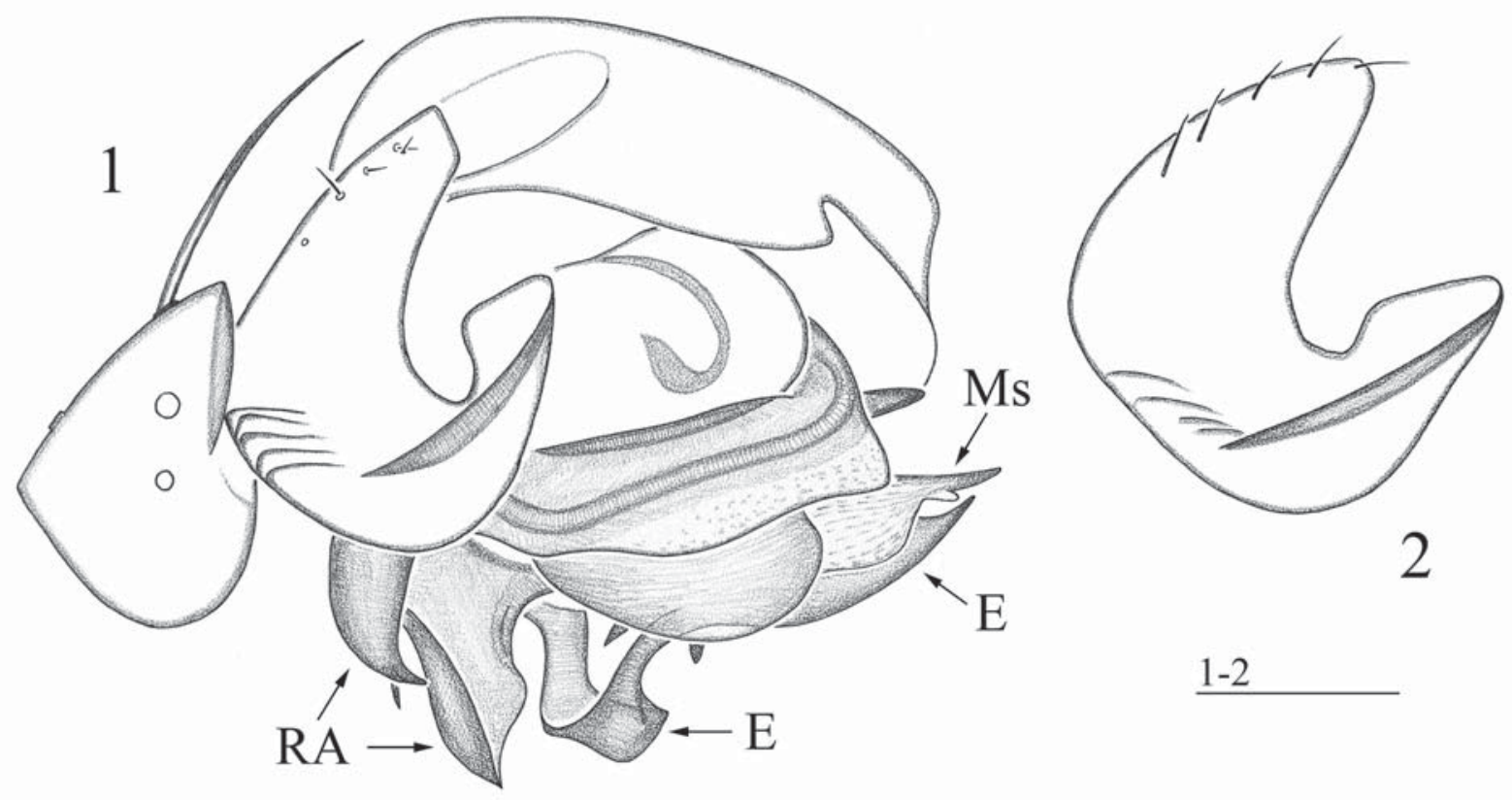

$1-2$
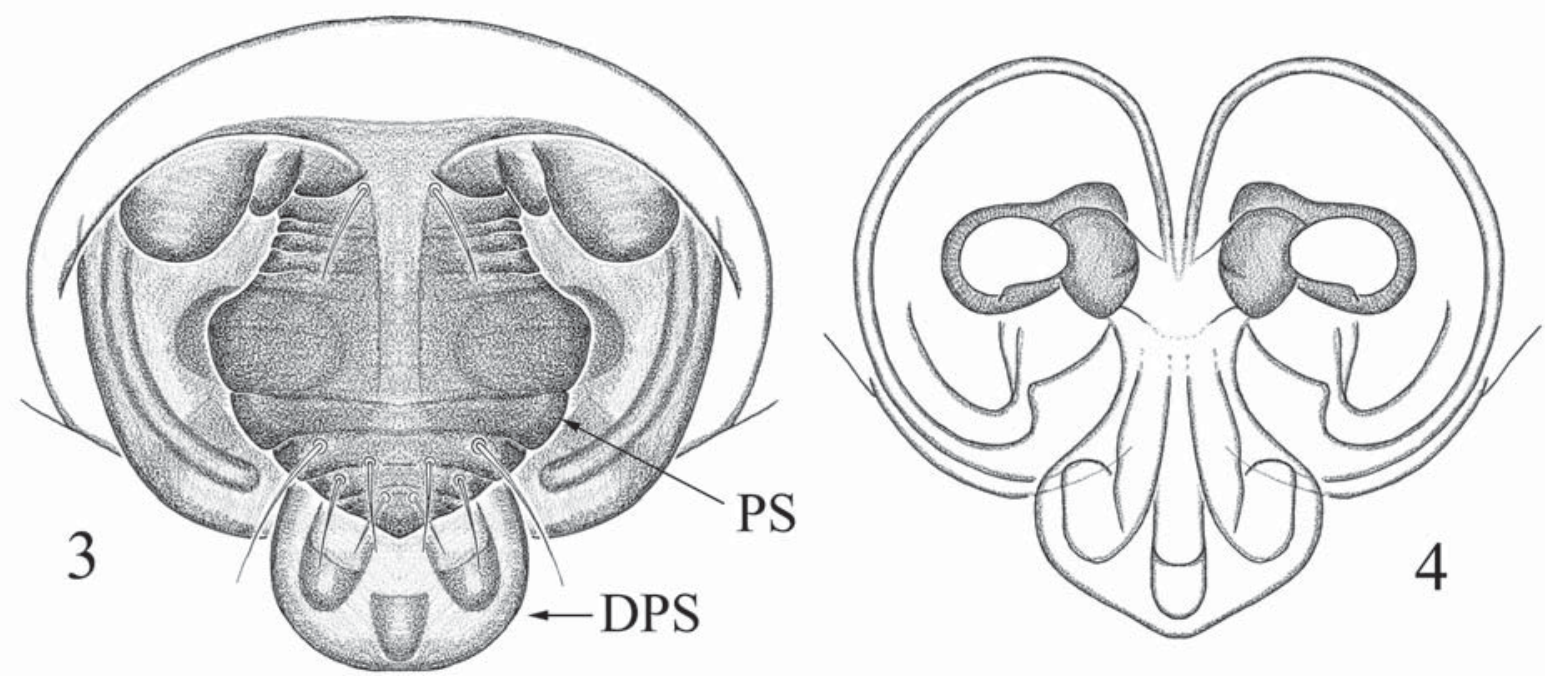

Figs 1-4. Centromerus nurgush sp.n., $\sigma^{\top}(1,2)$ and $+(3,4)$ paratypes: 1 - right palp, retrolateral view; 2 - paracymbium; 3 epigyne, ventral view; 4 - cleared epigyne, dorsal view.

Рис. 1-4. Centromerus nurgush sp.n., паратипы $\sigma^{7}(1,2)$ и $+(3,4): 1$ - правая пальпа, ретролатерально; 2 - парацимбиум; 3 эпигина, вид снизу; 4 - просветлённая эпигина, вид сверху.

DESCRIPTION. Male. Total length 2.08. Carapace 1.03 long, 0.83 wide, yellow to pale brown, unmodified, with grey radial stripes and a darker margin. Chelicerae 0.38 . long, anterior margin with three denticles differing in size, posterior margin with 2-3 very small denticles with poorly separated bases. Leg coloration as in carapace. Leg I, 3.54 long $(1.00+0.33+$ $0.90+0.78+0.53), \mathrm{IV}, 3.66$ long $(1.00+0.33+0.95$ $+0.85+0.53)$. Chaetotaxy. Fe I: 1-1-0-0, II: 1-0-0-0, III-IV: 0-0-0-0; tibiae and metatarsi spineless. Tm I 0.40 . Metatarsi IV without trichobothrium. Palp (Figs 1, 2, 5-10): Cymbium unmodified, posterodorsal outgrowth absent. Paracymbium toothless, anterior and apical pockets merged into a single shallow pocket; middle part of paracymbium with fine furrows. Radix extremely modified: proximal part narrowing and curved into a hook, distal part with two radical apophyses and a long, very narrow spine-like process (" $\mathrm{X}$ " in Figs 8, 9). Embolus long, swollen in middle part. Lamella characteristica large, wide and membranous. Terminal apophysis either absent or highly reduced and merged with base of lamella characteristica (" $Z$ " in Fig. 5). Membrosclerum with a sclerotized base and a membranous main part. Abdomen 1.08 long, 0.75, dark grey.

Female. Total length 2.03. Carapace 1.00 long, 0.70 wide. Chelicerae 1.00 long. Leg I, 3.11 long $(0.88+$ $0.25+0.80+0.70+0.48)$, IV, 3.37 long $(0.93+0.28+$ $0.93+0.75+0.48)$. Tm I $0.40(0.40-0.43)$. Abdomen 


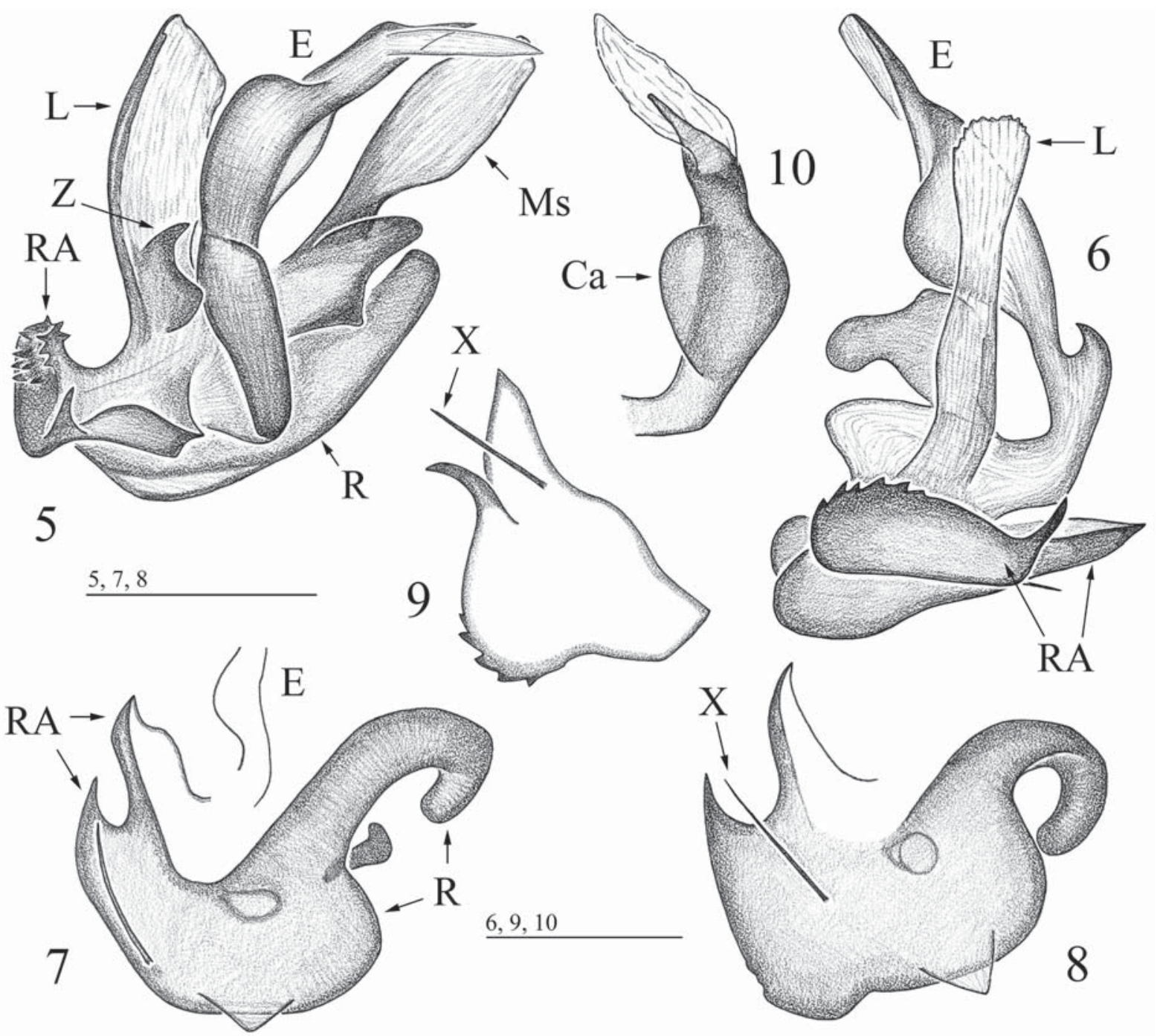

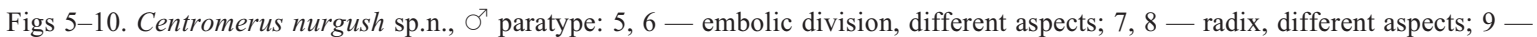
radical apophyses, distal end, front view; 10 - embolus.

Рис. 5-10. Centromerus nurgush sp.n., паратип О’: 5, 6 - эмболюсный отдел, разные аспекты; 7, 8 - радикс, разные аспекты; 9 - радикальные апофизы, вид с торца; 10 - эмболюс.

1.15 long, 0.75 wide. Epigyne (Figs 3, 4): Proscape cordate, with a narrow base, dark with reddish tinge, well-sclerotized, slightly wrinkled. Lateral lobes and stretcher merged together into a rounded distal part of scape. Body and leg coloration, as well as chaetotaxy as in male.

VARIABILITY. The body size in males varies from 1.95 to 2.20 , in females from 1.63 to $2.20, \mathrm{TmI}$ is $0.40-0.43$ in both sexes. The shape and the number of denticles on the distal radical apophysis are also slightly variable.

TAXONOMIC REMARKS. The new species is similar to the Siberian C. clarus (L. Koch, 1879); the male differs well by a toothless paracymbium, a wider and membranous lamella characteristica, the presence of two radical apophyses (C. clarus has only one which is long and straight), a strongly curved proximal pro- cess in the radix, as well as by some other small structural details of the embolic division. The proscape in C. nurgush sp.n. is cordate in shape, larger, darker and much more sclerotized than in $C$. clarus.

DISTRIBUTION. The new species is known only from the type locality.

ACKNOWLEDGEMENTS. We are very grateful to Lyudmila Tselishcheva whose collections have been used here. We also thank Sergei Golovatch who kindly checked the English of an advanced draft.

\section{References}

Esyunin S.L., Laetin A.M., Tselishcheva L.G., Lyapunov A.N., Tiunov A.V. 2011. On the spider fauna (Arachnida: Aranei) of the Kirov Area, Russia // Arthropoda Selecta. Vol.20. No.4. P. 283-318. 
Gnelitsa V.A., Ponomarev A.V. 2010. A new Centromerus Dahl, 1886 (Aranei: Linyphiidae: Micronetinae) from the south of the Russian plain // Arthropoda Selecta. Vol.19. No.4. P.265268.

Saaristo M.I., Tanasevitch A.V. 1996. Redelimitation of the subfamily Micronetinae Hull, 1920 and the genus Lepthyphantes Menge, 1866 with descriptions of some new genera // Ber. nat.-med. Verein Innsbruck. Bd.83. P.163-186.

Tanasevitch A.V. 1987. [A new genus of spiders of the subfamily Erigoninae (Aranei, Linyphiidae) from western Kazakhstan] // Biol. Nauki. No.11. P.72-75 [in Russian, with English summary].

Tanasevitch A.V. 1993. A new species of Trachelocamptus Simon from western Kazakhstan (Arachnida: Araneae: Linyphiidae: Micronetinae) // Reichenbachia. Bd.30. Nr.2. S.5-6.
Tanasevitch A.V. 1996. Two new genera of the family Linyphiidae from Tuva, South Siberia, Russia (Arachnida Aranei Linyphiidae) // Arthropoda Selecta. Vol.4 (for 1995). Nos 3/ 4. P.65-69.

Tanasevitch A.V. 2004. Two new erigonine spiders from the steppe of the East European Plain (Aranei: Linyphiidae: Erigoninae) // Arthropoda Selecta. Vol.13. Nos 1-2. P.63-67.

Tanasevitch A.V., Piterkina T.V. 2007. Four new species of the spider family Linyphiidae (Aranei) from clay semidesert of western Kazakhstan // Arthropoda Selecta. Vol.16. No.1. P.23-28.

Responsible editor K.G. Mikhailov 